\title{
Fatherhood, Gender and the Making of Professional Identity in Large Law Firms: Bringing Men into the Frame
}

\author{
Richard Collier *
}

\section{I.Introduction}

The dilemma of fathers in law firms is as complex as it is solvable. Brought to the firm as driven associates, these men strive to prove themselves in a legal arena that measures dedication in terms of hours logged. In response to a new generation of lawyers demanding lifestyle concessions, firms have adopted leave and part-time policies. Men, for the most part, have been non-participants in these programs, continuing to climb the firm's time-demanding ladder (Cunningham, 2011 p 1008).

I have heard anecdotally here people say I really wouldn't want my child to come and work in a law firm ... they just know what the working hours are going to be. But these men who reflect never say 'I wish I'd spent more time in the office' ... it's 'I wish I'd spent more time with the family. (Human Resources Director, female)

The primary focus of policy discussion within the debate about gender equality in the world's legal professions has tended to be a diverse set of concerns associated with aspects of the professional situation of women in the field of law (Schultz and Shaw, 2008). The past two decades has witnessed a marked increase in empirical and theoretical research on this topic; and a rich body of feminist scholarship in law has raised important questions about the legacy of the gendered cultures of a historically male dominated profession; questions about men's practices, power, privilege and accountability (see for example McGlynn 1998; Mossman, 2006; Sommerlad, 2002, 1996; Silus, 2003). These gendered cultures are now widely seen, across an array of policy debates and research, to have shaped the socially structured world of law in distinctive ways - ways, importantly, that have had deleterious consequences for women lawyers that they do not for men. 
If we dig deeper, this literature is marked by a central concern to explore how questions of gender intersect with a set of ideas about parenting, care and commitment at the interface of women's and men's family practices and employment in legal careers (Sommerlad and Sanderson, 1998) At the present moment, certainly, many organisations within and beyond the regulatory structures of the legal profession seek to support a rhetorical commitment towards gender equality with a raft of diversity and inclusion initiatives (see Headworth, 2016); by enhancing, for example, diversity and talent management processes in ways that might challenge the continued dominance of men within the upper echelons of the legal profession and tackle problems around women's career advancement (Ashley and Empsom, 2013; also Braithwaite 2010; Ashley, 2010). Yet it remains the case, a phenomenon observed internationally, that the impact of these gendered cultures appears entrenched; a form of masculine domination profoundly difficult to dislodge, evidenced by continued male labor market dominance at senior levels in the profession and the persistence of, in some accounts growing, gendered divisions or 'segmentations' within the law generally; the emergence of what has been termed a new 'precariat' in legal practice (Sommerlad 2016; also Ashley and Empson, 2013). Almost a century on from the Sex Disqualification (Removal) Act of 1919, when women were permitted to join the profession for the first time, the result is what Savita Kumra has termed a 'disconnect' between a rhetoric of change and the reality regarding gender equality in the legal profession (Kumra, 2015).

This debate, however, is routinely framed in a certain way; whereby, more specifically, and all too often, the practices of men fade from view. It is a debate, that is, in which men are somehow seen, and yet not seen, as men (see further on this idea in law Collier 2010; Dowd, 2010), with gender equality routinely framed as the legal profession's 'woman problem'. Contemporary research and policy on balancing work and family life more generally has tended to focus on mothers' lives with, Ruspini and Crespi (2016) observe, a distinct lack of research on the intersections between fatherhood, work-life balance and gender. At the same time, Madrid notes, "there is a lack of systematic research on fatherhood that might be emerging among the most privileged and powerful men" (2017, 
p 241). What happens, however, if we reconfigure and 'turn on its head' this debate and interrogate fatherhood within conversations about parenting and gender equality in the law? Or, as Fredman has put it (2014) in this journal, if we 'reverse roles' in our analyses of law by 'bringing men into the frame'?

This article, rather than focusing on women's parenting in the context of family life and paid employment in the legal profession, unpacks the relationship between men, fatherhood and gender within the specific context of large corporate law firms. Asking the law's 'man question' (Dowd, 2010) makes it is possible to unpack hitherto underexplored and revealing aspects of the gendered dynamics of identity formation as a legal professional in this sector (see further on this idea Sommerlad, 2007; Francis and Sommerlad, 2009). As Hearn et al (2016, p 57) ask "is it really possible to analyse professions and professionalization without considering gender and gender relations"? The paper begins from the premise that "gendering applies as much to men and masculinities as to women and femininities: Gender is not a synonym for women" (Hearn et al, 2016, p 59). A closer engagement with fatherhood, I shall argue, sheds much light on behaviour and practices that the wider legal profession literature suggests hamper equality at a more general level. It further adds a complexity to understanding of the roles of women and men in this area of the legal labour market.

\section{A Note on the Background Research}

The following reading draws, in part, on previously unpublished interview data derived from a qualitative empirical study of fatherhood in large corporate commercial 'City' law firms initially funded by the Socio-Legal Studies Association (henceforth SLSA), alongside a study of gender, work and wellbeing in the law funded by the Society of Legal Scholars. ${ }^{1}$ The paper also engages with two ongoing studies, funded by the

\footnotetext{
*Newcastle Law School, Newcastle University, UK; E-mail:Richard.collier@newcastle.ac.uk
} 
Leverhulme Trust and the charity Anxiety UK, of wellbeing and work-life in the law, ${ }^{2}$ further addressing themes in the growing secondary literature and other recent international empirical studies of work-life balance in the legal profession. ${ }^{3}$ The SLSA research itself built on earlier research project funded by the British Academy, published in the book Men, Law and Gender; Essays on the 'Man' of Law (2010). ${ }^{4}$ The present study involved semi-structured interviews with twenty male solicitors and three Human Resource managers (the latter all female) located within large corporate commercial law firms in the City of London. ${ }^{5}$ This is a sector of the profession in which questions of gender equality, diversity and inclusion have become distinctive features of the contemporary legal landscape (Sommerlad et al, 2010; Webley, 2015; Muzio and Tomlinson, 2012). It is a field of legal employment marked by a common pattern of rigid and demanding schedules, traced back Campbell and Charlesworth (2012) suggest, to the indirect pressures exerted by the widespread system of 'billable hours' as a tool for measuring and controlling the work of salaried solicitors (see also Flood, 1996); an area of work, that is, shaped by a 'long-hours' culture, the need for strong organizational commitment and a subjective recognition of the seeming inevitability, in terms of what it will take to 'get on' in such a firm, of an individual acceptance of a bottom-line need to meet client-led demands (Wald, 2010).

\footnotetext{
${ }^{1}$ Socio-Legal Studies Association (Small Grant Award), Fatherhood, Lawyers and Work Life Balance in City Law Firms; Research Activities Fund Society of Legal Scholars, Wellbeing in the Legal Profession. The present paper, drawing on unpublished material, considers how ideas about fatherhood and gender shape professional identity in this field and interrogates, in particular, how more recent structural changes in the profession and developments in sociological work shed light on understandings of fatherhood in this context (on theorizing masculinity see further Collier, 2015, 2013).

${ }^{2}$ Leverhulme Trust Research Fellowship award 2017-18, Wellbeing, Law and Society: Politics, Policy and Practice-A Socio-Legal Study: Anxiety UK Katherine and Harold Fisher Award (2018) Experiences of Anxiety Amongst Junior Lawyers.

${ }^{3}$ Balancing Law and Life in the Legal Profession, Australian Research Council Discovery Project (20122014, Lead Investigator Margaret Thornton, College of Law, Australian National University; PartnerInvestigator, R Collier, Newcastle Law School). See further Thornton 2016a, 2016b, 2016c.

${ }^{4}$ R.Collier, Work Life Balance in Law Firms, British Academy [SG ref 31920]. These earlier interviews took place with a different sample of male lawyers (not just fathers) and this project is discussed further in Collier 2010, Ch 6 .

${ }^{5}$ It is recognised the self-selecting nature of interviews, arranged with the assistance of HR staff, means the men interviewed may be those who already have personal interest in or awareness of the issues discussed in this paper. Quotes from HR Managers are used as they relate to perceptions of the 'bigger picture' of parenting in the law firm.
} 
In other published work, I have sought to explore the theoretical dimensions of this 'gendering of men' in law firms by focusing on the conceptualisation of men and masculinities in the context of these gender equality debates in law (Collier 2015, 2013). The aim of this paper is more precise and straightforward; to use interviews with a group of male lawyers who are fathers, a set of textual responses, in such a way as to unpack how fathering practices connect to certain ideas about professional identity formation and understandings of what men do (their 'family practices', to follow the sociologist David Morgan (1996) in the light of more recent developments in the legal profession literature. By placing these debates in this wider context, the paper considers, in addition, how contemporary sociological scholarship on fatherhood can help us reframe these debates about gender in the profession.

Finally, by way of introduction, it is recognised there are methodological limitations to analyses such as this in terms of the size and sample selection (Gilding, 2010; see also Madrid, 2017, 2013). ${ }^{6}$ Unlike the earlier study of male lawyers and work-life balance in law (Collier 2010, Ch 6), all solicitors involved in this tranche of interviews were coresidential fathers with children of varying ages. Only selected issues pertaining to men's fathering practices are considered in this discussion. The very idea of securing a 'balance' between work and life is contested conceptually (Weldon-Johns, 2016), raising concerns that transcend the questions about fatherhood and workplace commitment central to what follows (see Drew et al, 2015; Rhode, 2001: also Carlson et al, 2009; Gregory and Milner, 2009). Indeed, I shall suggest, the very idea of work-life balance needs to be transcended in this area in the light of social, economic and technological changes that have impacted profoundly on working practices in the legal profession (see below: also Thornton, 2016a, 2016b). A focused relatively small-scale qualitative study, moreover, does not seek to be representative in its findings; nor does this reading disavow the intersectional nature of gender in exploration of men's lives (see further, in the context of professions, Hearn et al 2016); how issues of, say, race and ethnicity, sexuality, social class, physical ability, age and health (amongst others) shape social experience at

\footnotetext{
${ }^{6}$ See also above $\mathrm{n} 5$.
} 
moments in the life course (a point I shall return to); nor the continued significance of social and cultural capital in recruitment and selection processes in this field of law which facilitate the reproduction of legal elites (Cook et al 2012).

The article, rather, in summary, 'diverts the gaze' from women to men's practices to contribute to what has become a growing debate within legal scholarship and studies of the legal profession about how it might be possible to better engage men in organizational change strategies in developing gender equality in law (see Flood and Howson, 2015). This is part of a heightened political conversation taking place internationally about the power of the cultural forms of masculinity and of the dominant groups of men in society with which they are associated. If much is now known about women in the law, in short, what of those men routinely positioned as relatively 'unencumbered' figures in terms of their caring commitments? (Neuberger, 2014). What do we know, and what do we not know? What might mean to be both a 'good father' and a 'good lawyer'?

\section{Setting the Scene: Approaching Fatherhood in the Legal Profession}

As noted, the relative absence of an interrogation of fatherhood in the context of the legal profession stands in marked contrast to the engagement with women's parenting at the interface of work and family in law at the present moment. Within the now vast international literature on women in law, as well as within broader cultural representations of contemporary legal careers, we tend to find a number of recurring themes relating to parenting ${ }^{7}$ for example, about the presence, or otherwise, of a 'baby bar' within legal professions historically dominated by men (McGlynn, 1998); the persistence of the 'double-bind' experienced by many women in law when it comes to combining a legal career with family life; concern with the potential, and limits, of

\footnotetext{
${ }^{7}$ In 2015 the cover of the Ashgate publishers Law and Society catalogue, for example, featured the following image: a woman lawyer holding up, and seeking to balance, on one hand a briefcase and mobile phone and, in the other, a baby. It is precisely an attempt to reveal the 'hidden history' of women's lives in law that underscores recent initiatives such as the First 100 Years: Celebrating Women in Law project: see further http://first100years.org.uk/
} 
various 'agile' and flexible working policies as ways of addressing problems in this area (Thornton and Bagust, 2007; see for example Connelly, 2017).

Throughout these discussions, certain assumptions about parenting, care and commitment in relation to motherhood - in ways, crucially, that are markedly different to fatherhood are seen to then connect to a set of related problems; around the idea of a maternal wall and glass ceiling when it comes to promotion to senior levels and securing partnership in law firms (Wald, 2010; Pinnington and Sandberg, 2013; Buonocore Porter, 2006); how, notwithstanding the fact women have for some time made up the majority of new entrants to law, and for all the cultural changes that have occurred within the profession in relation to equality and inclusion, this is a partnership gender ratio that stubbornly persists, ${ }^{8}$ how the well-documented gendered dimensions of attrition from the law, continued salary differentials and concerns around the difficulties that face many women returners to the profession, are each enmeshed with wider questions about the gendering of commitment and care (Duff and Webley, 2004; Kay et al, 2013). These are all questions that continue to resonate in the contemporary legal landscape (Cohen, 2017; Isaacson, 2017).

One cannot, of course, generalise across the legal profession or, indeed, specific areas of the large corporate law firms that are the focus of the discussion to follow. Nonetheless, the dominant law firm paradigm, Thornton and Bagust (2007) suggest, is one that has historically conceptualised fathers, in marked contrast to mothers, as paradigmatic degendered subjects; as embodiments of a form of 'bleached out' legal professionalism, somehow detached from the cultural associations with care traditionally attributed to mothers:

Fatherhood does not exert the same devastating effect on a career as motherhood. Most lawyer fathers [in this study] had partners who were full-time, stay at home mothers, which attests to the conservative lifestyle of those in corporate practice. In any case, fatherhood has conventionally been viewed as an indicator of marriage and stability -

\footnotetext{
8 The 2014 Chamber Gender in the Law Survey thus notes the 'long road ahead for equality in the law...Female lawyers have made up over 50\% of new entrants to the profession since 1993, but it's clear they're still not progressing to the highest roles", concluding "its up to law firms to turn the hot air of the past into winds of change": see http://www.chambersstudent.co.uk/where-to-start/newsletter/2014-genderin-the-law-survey
} 
factors deemed to justify higher pay (Thornton and Bagust, 2007, p 784: see also Campbell, 2013).

It is important to ask, however, who is this father figure? Motherhood and fatherhood, after all, are interdependent constructs, social and experiential changes in one interlinked inescapably to shifts in the other (see Miller, 2011; also Kugelberg, 2006). Yet within these debates fatherhood continues to be conceptualised, broadly, via a binary of men's public and private commitments, responsibilities and dependencies (or, more accurately, lack thereof: Marsiglio and Pleck, 2005); a frame in which care and emotion work have been defined more generally as feminine and, at times, as something men are not capable of doing (see Hanlon, 2012).

At the same time, this is a fatherhood ideal associated within the literature with some distinctly gendered assumptions about the nature of legal professionalism itself; in relation, for example, to gendered ideas about what constitutes workplace authority and presence (Thornton, 1998); the function of merit in reproducing structural inequalities (Sommerlad, 2010; Thornton, 2013); the reproduction of processes of embodiment, sexualisation (Thornton, 1996) and 'everyday sexism' within the legal profession; questions about the nature of such commitment and what is required at a subjective level to pursue a successful career in the law (begging the question, of course, of what is meant by success in the first place, a point to which I shall return: see also Groysberg and Abrahams, 2014; Bostock, 2014). This is, Webley and Duff have argued, a debate precisely about issues of values and, in the immediate context, what it might mean be feel oneself to be - and to be seen by others as - both a 'good parent' and a 'good lawyer' (Webley and Duff, 2007).

These are assumptions about fatherhood however, and a broader paradigm in relation to men's parenting that, I have argued in more detail elsewhere, is shifting in two important respects (see further Collier 2013, $2010 \mathrm{Ch}$ 6). In setting the scene for the interviews with fathers to follow, and in brief, first, social and demographic changes relating to families, work and parenting are prompting the need for the legal profession to reconsider the place of men in these work/life and gender equality debates in law. This underscores 
concerns about the recruitment and retention of high quality lawyers and implications for law firms of a rising number of dual-earner households (Christensen, 2005). At the same time, generational shifts in the aspirations and experiences of 'Millennial and Gen X' lawyers (Bullock, 2016; Wallace, 2006), a later age of first parenting (Plickert and Hagan, 2011) and new configurations around cross-generational caring obligations have become key features of the debate about work-life balance in law. Set against the backdrop of an increasingly hypercompetitive (and in some account hyper-masculine) legal profession, these shifts link to the related argument that new kinds of pressures are now emerging for lawyers, women and men (Thornton, 2016a, 2016b, 2016c). These issues are central to increasingly resonant debates we are now seeing in the legal profession about the wellbeing and mental health of lawyers (see, for example, Junior Lawyers Division 2018a, 2018b; Collier, 2016).

Second, it is important to remember that this is a conversation around gender equity in the law that intersects with a far broader reappraisal of social and legal norms relating to fatherhood and men's family practices (Collier and Sheldon, 2008; Gregory and Milner, 2011); a political terrain that has shifted the way men's individual and collective responsibility to address gender inequality is understood (see Flood and Howson, 2015). The UK, like other countries, has experienced over the past two decades a series of legislative and service delivery initiatives aimed at addressing men's parenting at this interface of work and family life (Stanley, 2005; Burgess, 2007; James, 2009). A succession of legal reforms, including but not confined to provision of parental leave and flexible working (Atkinson, 2017; Dermott, 2001), have sought to get men more involved in child care and domestic labour within an employment landscape in which women make up an increasingly large part of the workforce (Ruspini and Crespir, 2016); a landscape exemplified by the contemporary legal profession. At the same time the research base on fathers in the UK has expanded considerably regarding both quantitative datasets and qualitative studies addressing the experiences of fathers in varied forms of co-residence and relationships with dependent and adult children (see Goldman and Burgess, 2017). 
Taking these two drivers of change together therefore, it is suggested, contemporary fathers in the legal profession may also not be able to 'have it all' and need recognise the potential impact parenthood can have on a demanding career (Hinsliff, 2015 p 41: see further Dermott, 2006). A growing body of research suggests, certainly, that both men and women in the law can and do struggle with the 'competing devotions' of work and family (Blair-Loy, 2003) resulting from shifts in relation to their employment and caring commitments (Thornton, 2016a), albeit that they may do so in different ways (see further below).

The above developments provide the backdrop to the reading of textual responses to follow in Part Three of this paper. Having set the scene for the discussion in the remainder of this article, drawing on the voices of male lawyers themselves, I unpack this interplay of gender, fatherhood and professional identity in large law firms in the context of a new political terrain around men and gender equality in law.

\section{Unpacking the Good Father/Good Lawyer: Family Practices and the Reconciling of Work and Family}

Fathers tend to be far more involved in the whole upbringing, child raising ... I heard an interesting comment from a friend who is senior at [firm name], she made a comment about me and my wife, well, she said, on the scale of male friends I have you are towards the top end of being involved, in that you at least know their names... (laughs) (Partner)

It is a recurring theme within recent sociological studies of fatherhood and intimacy that contemporary experiences of fathering can be marked by often contradictory ideas around what being a good father entails; ideas that shift across the life course as family transitions occur (birth, marriage, divorce, re-partnering for example) and, importantly, as men age (see further, and generally, Miller, 2011; Dermott, 2008; Doucet, 2006; Hobson, 2002). Curiously, the ambiguous nature of this 'good father' ideal, and the conceptually contested, multi-dimensional nature of fatherhood itself (Hauari and Hollingworth, 2009), was a theme that ran throughout the interviews with male lawyers. Common reference 
was made to the importance of being a "good dad, you know... it's really important to me, more than anything really" (Partner). There was far less agreement, however, as to precisely what this involved. For some it entailed engaging in 'hands-on' parenting; physically 'being there', as much as employment in a large commercial law firm would allow. Others equated good, active-fathering primarily, if not exclusively, in terms of a more traditional male breadwinner model; being the good provider whereby, by "working so hard I am doing the best for my family" (Associate).

I want my kids to strive to be the best, so I have to be that example ... I have to be at work, I have to be away, they have to see that. (Partner)

Mapping to this theme of fluidity around fathering identity in sociological work, however, within the majority of accounts the men appeared to slide between, and at times struggle with, contrasting discourses around the nature of such responsible fatherhood and this provider/carer binary: navigating, that is, the simultaneous pressure for having a successful career and embodying an involved fatherhood (Madrid, 2017).

I've always had a real internal struggle between managing my drive and my commitment to family ... I've always wanted to be that family man, never to just be the breadwinner... (Partner)

By interrogating the good father ideal more closely, however, it becomes possible to see more clearly how at a micro-level a range of 'everyday' experiences and practices relating to fathering came, on the part of these co-residential fathers in large law firms, to intersect with specific aspects of their work as City lawyers; doing so in ways, importantly, that shape some distinctly gendered ideas about the nature of professional identity and career 'success'.

This is illustrated across three dimensions each of which, taken together, highlight how the constitution of a particular kind of gendered professional identity can entail diverse, often contradictory, assumptions about what it means to be, simultaneously, a 'family man', a 'good dad' and a 'good lawyer' (on this idea of the 'family man' see further Coltrane, 1997; Collier, 1995). 


\subsection{Being the 'Good Dad': Balancing Work and Home}

There was common agreement amongst interviewees that men's experience of fatherhood was changing (see also Collier, 2010; Madrid, 2017; Miller, 2011). All the men expressed the view, for example, there were growing social expectations on fathers in the legal profession to 'be there' for their children in ways that, some readily admitted, their own fathers had not been:

My father ... doesn't communicate with anyone really ... I have a very different relationship with my children ... all of my friends, my generation, everyone seems to have the same sort of story ... I think we're better at expressing [intimacy] than previous generations. (Partner)

Frequent reference was made to a personal aspiration and more general desire on the part of men within law firms, regardless of whether married, co-residential or separated, to be a 'better kind' of dad than many men had been in the past:

Twenty years ago ... if a man attended the birth of your child ... well, my father turned up and was presented with the child and you weren't allowed in the hospital, to change nappies all that sort of thing. Now it's as if you don't do that it's generally frowned upon... (Associate)

These new cultural expectations on fathers, however, appeared double-edged. On the one hand, this was a transformation in fathering to be welcomed; a culturally resonant new or active father ideology, as discussed above, of benefit to women, children, men and, curiously, the law firms in which they worked. Thus, looking at fathers in her firm, another female Human Resource Director described her experience of men's greater involvement in child care, and changing aspirations as parents, as a productive "safetyvalve" for the over-worked male lawyer; men who might otherwise be "sitting in the office every evening always working, you know, e-mailing at midnight"; the very men castigated by Lord Neuberger in his 2014 Rainbow lecture on Diversity and Equality in the legal profession as constituting a force of resistance in promoting greater gender equality in law (Neuberger, 2014); 
Men are realizing that their children and their family are the most effective antidote to the pressure of work. So being able to go home to their children makes it all worthwhile ever though they are having an absolutely shit horrible time at work ... people are realizing that there is nothing quite as good as bathing the kids after an awful day. (HR Director)

On the other hand, several fathers stated they "had it harder, really" (Associate) than previous generations of male lawyers. The latter were men who had worked in a legal profession at a time when there were more opportunities for fathers to have both "dad's time" (Associate) and a professional career. Recognizing the flexibility stigma that could impact on both women and men in the profession (see Cunningham 2001; Darby, 2009; Thornton and Bagust, 2007, p 805; Thornton 2016a; also Coltrane et al, 2013; Rudman and Mescher, 2013), it was suggested that male lawyers in the past may have actually spent more time with their children than those within the market-driven, hypercompetitive legal profession of today, notwithstanding the presence of any new cultural ideas around fatherhood and provision of policies around agile working; "you know, perhaps it was just more, I don't know, just a more civilized profession" (Associate).

Following Kumra's (2015) identification of a gap between a rhetoric and reality of change, this draws attention to a tension between cultural ideas around fathering and what a growing body of research on the contemporary legal profession suggests has become a dominant working culture and set of practices that is in several respects inimical to such an ideal (Thornton, 2016a). This is, Thornton (2016b) suggests, a legal profession increasingly 'squeezing the life out of lawyers' in the force of its market embrace; a workplace marked by a hypercompetitive professional culture and commitment to a form of hyper-mobility and instantaneous communication; a way of life framed by a form of 'informal flexible work' (Thornton 2016a) in which commitments to an individualistic meritocracy, as Wald (2010) has put it, come to foreclose the possibility of flexibility in work; doing so precisely by reproducing an ideology which requires 24/7 commitment and physical attendance as a proxy of loyalty and near-instant responsiveness (see further on this '24/7' workplace and realigning of work/life Wajcman, 2015: Crary, 2013). 
This is the backdrop against which fathers' competing work-family demands were enmeshed in the interviews with a range of comments on the prevalence of poor wellbeing in the legal profession, for both women and men (see further Chan, 2014; Thornton, 2016b), encapsulated in the following observation by one law firm Partner:

The personal issue for me is the stress it generates. I used to think I enjoyed stress ... I'd used to sleep well every night ... but I've now got health issues ... brought on by stress. I take a tablet, it goes away. But obviously it has an impact on me I wasn't aware of ...That's not the getting to Partnership...it's, it's whenever you achieve something you want more, then the next stage, then the next ... it is never ending, but I absolutely love it, and I love the material benefits. (Partner)

The frequent if cyclical need to work long hours, especially in areas such as transactional work, to demonstrate such commitment regardless of stage of career, was seen as a source of potential stress for fathers as well as mothers in law ("it doesn't get easier for Partners you know, it's just a different level of pressure" (Partner): see also Rimmer, 2015). I have suggested elsewhere (Collier 2016) that in relation to gender these expressions of poor wellbeing in the law may, at first sight, sit uneasily with research highlighting men's relative reluctance to express weakness within organisations, including law firms (see, on the idea of the 'weak man' Collier, 2010). This aligns with McQueen's (2017) suggestion that men in the workplace, in navigating the boundaries between traditional performances of masculinity and more emotionally expressive ways of being 'manly', can in fact be caught between two discourses: 'it's good to talk' versus 'boys don't cry'.

The present study and interviews with fathers, however, suggest a closer examination of the interconnections between men, work and family practices makes it is possible to bring into sharper focus just how a set of assumptions about the relationship between fatherhood and gender intersect in the making of professional identity as a good lawyer and 'family man'; and, in turn, how certain beliefs about men, work and the changing nature of legal professionalism 'hold together' what may at first seem, on the surface, to be apparently contrasting ideas about fatherhood. This point requires clarification. 
It was recognised that whilst it entailed a constant degree of self-reflection and selfdiscipline, a successful father-lawyer could, if he chose, reconcile these competing demands of work and family. This was a recurring theme across both these and earlier interviews with male lawyers (see also Longlands, 2014):

If you want to make something work you can make it work. (Partner)

I make it work .... I've got a very supportive wife ... my dad can't make a cup of tea, I'm not a lot better ... that creates issues, she gets bored she's stuck with kids, but on the whole it works very well ... she is extremely supportive' (Partner)

Contrasting markedly to cultural depictions of women's parenting as being somehow naturally given (in ways that a man's is not: Asher, 2011) it is intriguing, however, that certain family practices, and not others, tended to assume symbolic relational and familial significance in this process. Thus, the common arrangement amongst residential fathers with younger children in such large law firms, it was agreed, was for contact to occur, wherever possible, at one end of the day (highlighting the importance of the 'good night kiss' as Madrid (2017) terms it). The demands of working in a large law firm meant the majority of fathers with young children saw "very little" (Partner) of them during a typical working week:

I see them in the evenings, briefly in the mornings. (Partner)

The reality is I see my children in the morning, and that's that. I don't see them in the evening .... yes, it impacts, my wife gets annoyed about it, but it doesn't affect the children (Partner)

Albeit for short periods, however, undertaking activities such as reading bedtime stories, attending bath times and having occasional breakfasts (with weekends 'family time' to such a degree as work allowed) were viewed, to follow Morgan (1997), as key family practices in marking an identity as a good 'hands on' father;

I get up early before the children, sometimes I wear a suit just so they will see me and associate it with me working, at least for breakfast, so they think I am working, then I will sneak into the study, then when they go to school I come out of my cocoon, make a coffee, go back to work ... (Associate) 
I get up at 5 and generally work from 5 till $6.15 \ldots$ my eldest gets up about 5 and sits in the study with me and tries not to talk, reads a book or writes or draws or something, and those mornings are very precious ... I leave about $8,8.30 \ldots$ I see the children every morning (Partner)

The symbolic value of such activities chimes with the depiction within recent sociological work on 'caring masculinities' (Elliott, 2016) and studies of contemporary fatherhood via the frame of emotion, an intimate relationship (Dermott, 2007; Miller, 2011; see also Collier, $2010 \mathrm{p} \mathrm{167).} \mathrm{That} \mathrm{is,} \mathrm{the} \mathrm{aspects} \mathrm{of} \mathrm{parenting} \mathrm{viewed} \mathrm{as} \mathrm{most} \mathrm{significant} \mathrm{by} \mathrm{these}$ fathers included not just their ability, as in this case as relatively well-paid lawyers, to provide for their families (traditionally presented as the breadwinner model) but also something else; the importance of having this intimate relationship with their children, as seen in the above quotes; even if in practice these family practices were, it was recognised, limited in terms of time and often facilitated by the care work and emotional labour of others, particularly women, whether partners, other family members or, frequently in this field of employment, paid help in the form of nannies; via an erasure, that is, of the obligations of men to engage in such care activities.

This highlights within this employment context the significance of a broader gendered global chain in relation to the provision of care (Wimmer and Schiller, 2002). It further supports the argument that men's careers in the corporate world are built via a reliance on women's work, either that of their wives or female domestic service (Madrid, 2017; Longlands, 2014).

Why is this significant? This suggests not only that the good father ideal within this organisational context accommodates notions of both the breadwinner and 'caring/new father' discourses, as discussed above (see also Ranson, 2012). Rather, a disposition to engage in childcare was itself seen as part of a professional identity as a lawyer-father, an incorporation of men in care that was nonetheless directly related to men's ability and possibility to choose where and when they participate in such caregiving (see further Bekkengen, 2006: Johansson and Klinth, 2008). Far from indicating a rejection of power and privilege, the embrace of affective, emotional qualities is itself consistent with a form of 'caring masculinity' (Elliott, 2016); how, precisely, it is no longer 'enough' to be a 
rational, career-oriented 'breadwinner'. Such a child-oriented masculinity, crucially, “...does not imply more egalitarian men (e.g. sharing responsibilities and practical tasks associated with children). In this masculinity, children are central, not women." (Madrid, 2017, p 243: see also Brandth and Kvande, 1998)

This serves to highlight, to follow Kumra (2015), an important aspect of the seeming disconnect between these cultural ideals of active fathering and the gendered structural realities of everyday family practices. Thus, as one Partner reflected, commenting on his

contribution towards work in the home, "Sometimes I suppose, yes, it does feel a bit like having my cake and eating it ...I definitely get to do the fun stuff, and that's good". It is change in fathering that, as Madrid observes, can be seen at the discursive level; a "case where discourses change faster than practices" (Madrid, 2017, p 251)

\section{2 'Daddy Big Man': Situating Fatherhood and the Blurring of Boundaries Between Work and Home}

Building on the above, secondly, the interviews draw attention to what is described within sociological studies of fatherhood as the performative, situated nature of fathering (Marsiglio et al, 2005). That is, what it meant to 'do fathering', to be the "kind of man, the man I want to be" (Partner), was something that varied across, and between, different spatial contexts. The following depiction of one law firm Partner's personal transition from what he saw as being an "aggressive and assertive" male lawyer at work to the "quite sensitive, caring" man and father at home illustrates this theme:

There was one fantastic occasion when my nanny called in sick and [wife name] was out of the country, and so I knew in advance it was go to be a very difficult call with lawyers on the other side ... I explained to my boys who were to at the time daddy was going to get angry on the telephone, and it wasn't angry with them ... I had my trainee at work patch me into the conference call, and while I was with them I was shouting on the phone, both boys were completely bemused, I had to call the trainee back to see what they had had heard as one of them was running my feet shouting 'daddy big man, daddy 
big man', and I was aware this could be heard by the Partner I was talking to [laughs]... Well, my whole team was on that call... (Partner)

This resonates with the argument that working from home during 'normal' hours continue to be encoded in law firms as an implicitly feminised space; somehow apart from the (still masculinised) domain of work (see Thornton, 2016a; Thornton and Bagust, 2007). This is a spatial gendering that, in turn, connects to the way an ideal worker status, as discussed above, may insulate men from negative stereotypes around care in ways it does not for women; whilst, at the same time, constructing the 'successful' women Partner in law firms as an individual who is herself somehow 'exceptional'; who has, at the very least, potentially sacrificed something with regard to her family life that fathers have not:

It's a competitive, tough environment, at associate level, they know it is tough to make Partnership, a lot of people just wouldn't dream of asking to work flexibly, because they would be terrified for the implications it would have on their career ... (Partner)

The development of law firm infrastructures and new technologies seeking to facilitate remote and agile working in law were seen by these interviewees to have shifted these situated everyday experiences of fathering in some contradictory ways; a model of fathering shaped by a far broader reframing of understandings of the work life divide as traditionally understood (see Thornton, 2016a; Turkle, 2011); a workplace, that is, in which, as noted above, lawyers male and female are increasingly never 'offline', potentially available $24 / 7$ if need be to meet (ever more intense) client demands (Thornton 2016a, 2016b: Collier, 2016). As one associate put it, referring to senior men in his firm:

Some of the senior people live in an utter bubble of work, they are picked up from home very early in the morning, driven in, work in the car, work in office, driven home, children in bed...they are always in a working capacity... (Associate)

Online technology has had a profound effect on the work and lifestyles of professional employees such as lawyers, exacerbating the tendency among such vocational salaried professionals to see their work at the heart of daily concerns (Gregg, 2010; also Crary, 2013). This aligns with a theme in recent sociological work exploring the 
interconnections between professional identity formation, overwork and the idea of the law firm as a 'totalizing' organization. In short, within traditional ideas of professionalism individuals such as lawyers were seen to enjoy relatively high levels of autonomy around the location and timing of their work (Engel, 1970; Sandberg and Pinnington, 2009). Within the context of contemporary legal professional practice, in contrast, as seen above, professional workplaces are characterized more by excessive working hours and increasingly demanding workloads; organizational processes that, in different ways, have served to reduce workplace autonomy, whether it be via escalating availability to clients, unpredictable workflows and so forth (Thornton, 2016c).

It is in this context, therefore, that the idea of overwork has been seen as a motive force within employment cultures that cut across the traditional domains of work and home and fuse personal identity intimately with the nature of work outputs (outputs that, importantly, are assessed in a myriad of ways, not least in relation to billable hours). In seeking to understand how and why skilled professionals such as lawyers would then become "willing slaves" to the organizations they work for, given the tensions this can produce in relation to family practices around care, as seen above in relation to these fathers, the very "totalizing" nature of such professional work and its connection to new ideas of autonomy has been seen as a key factor in shaping professional identities in such a context (Ashcraft, 2013). That is, Blagoev, Empsom and Ortleib (2017) suggest, many professionals tend to hyper-identify with this professional myth "...even up to the extent of becoming "corportate clones.... unable to recognize how work takes over their lives"; mirroring Thorntons (2016a) depiction of the corporate lawyer as a kind of flexible cyborg.

Importantly, and of significance in understanding fatherhood, this links overwork to the (gendered) ideal worker model discussed in feminist legal scholarship; an individual who will, or should, prioritize their work, minimize obligations outside it, and display loyalty and commitment precisely by working long working hours and displaying near constant availability. These are interconnections between professionalism and parenting identity, in other words, enmeshed with a production process that embodies the increasingly fluid, 
permeable divide between work and home un a more general sense (Wajcman, 2015); processes that are, I suggest, shifting experiences of fatherhood as well as motherhood. Yet with specific regard to fatherhood, my concern here, what this meant in practice was that the cultural ideas and aspirations around active fathering discussed above co-existed with subjective commitments to this working culture and set of practices that, it was simultaneously recognised, clashed with such an ideal. The 24-hour support and in-house facilities of the kind designed into many contemporary large law firm offices were thus seen by these fathers as an essential feature of their life in a 'global' legal practice, part of their 'doing' of family life;

We've got bedrooms, I've used them twice when I've finished 3 in the morning... We have a concierge service to book holidays, that's useful, there is a risk you can almost live here, you get out of hours meals, you can almost never leave the place (Partner)

What is significant in seeking to advance understanding of the gendered dynamics of identity formation as a legal professional is how these ideas about fatherhood appeared not simply to shape what care work and domestic activity these male lawyers did in the home (which, as seen above, and as other research suggests, could be limited). Their work as a lawyer itself helped define a distinctive gender identity as a kind of 'family man' and good lawyer. And, crucially, any recognition of these tensions between work and home for fathers did not necessarily result in a sense of personal dissatisfaction with such a model of working. It is at this point that a closer interrogation of fatherhood reveals how distinctive ideas about men's parenting came to coalesce in relation to gendered ideas about professional identity in such a way as to 'hold together' such apparent tensions; and, in particular, how understandings of what it meant to be both a good lawyer/father were mediated by reference to one central idea; the 'package deal' such a relationship with work entailed. The final theme will explore this point.

\subsection{Fatherhood, the 'Package Deal' and the Life Course}


For all interviewees, without exception, the already realised or potential financial rewards of pursuing a career in a large law firm enabled the adoption of a certain lifestyle and the securing of a social/career status as, more specifically, an 'elite' 'global' lawyer set within the context of an increasingly fragmented legal profession (Nicolson and Webb, 2005). Such self-identity as a 'global player', Longlands (2014) suggests, is itself intimately interconnected with ideas of value, success and status (and, with it, relatively high levels of renumeration). The acquisition of positional goods, I have argued elsewhere (Collier, 2010 p 179: also Longlands 2014), appears a particularly significant aspect of masculine self-identification with such ideas of professional success that, in the case of these lawyer fathers, developed more through the financial rewards received and their consumption of 'high end' commodities than through any more traditional sense of public service as a legal professional (see also Dinovitzer 2011; Hanlon, 1998). As one father in the study put it:

Who's got the best pram, you know? ... With my law profession father friends there is a bit of a game that goes on, well, 'I've done this with my son, I took him to soft play, we went to the golf ... look at me I'm such a great father, I've managed to organise my life so I can do X Y Z' and there is an element of competition coming in .... (Partner)

In terms of their day to day experiences of fathering, however, as seen above, this meant that the ability to participate in such consumption practices came at the cost (or 'tradeoff') of the long hours worked and high level of organisational commitment called for (Tienari et al, 2010). This was repeatedly referred to as "the deal" (Partner), part of the "package" (Associate), a successful lawyer in this area of legal practice would inevitably have to make (see further Townsend, 2002):

I have opened eyed chosen a career where there are lots of demands on my time. ..There are benefits to me and my family for that...if you can't take the heat get out of the kitchen, to be blunt about it. (Partner)

Importantly, the personal accommodations this deal was seen to entail for men who were fathers were shaped by ideas about paternal identity and responsibility. And significantly, looking back to discussion above, it was not so much the everyday demands of child care that primarily mediated this identity as a good father. It was, rather, an array of rather 
different associations between gender and commitment, and around the intrinsic/extrinsic rewards of a legal career, that shaped ideas of familial responsibility.

To be more precise, practices relating to fathering identities and relationships with their children were viewed as key markers of such a lifestyle, with the provision of private education, the purchase of expensive housing and acquisition of a range of cultural experiences recurring markers of success as both a father and a City lawyer. A female Human Resources Manager evocatively summed up what she saw as the resulting tension in the relationship between work, consumption and professional identity that could arise for many of the fathers around her in the firm:

I once had a Partner say to me, he's worked so hard he's missed his two boys grow up ... but then again he now has his posh cars and his big house so, well, I guess that's fine ... $\left(\right.$ HR Director) ${ }^{9}$

That is, for those men who were fathers, paradoxically, whilst this lifestyle was inimical to having flexibility in work, the need to maintain it 'in the name of family', drawing on more traditional ideas of the father as provider, was viewed as a central motivational force underscoring commitment to their career. This highlights the plural dynamics and forms of masculinity, emphasizing the multiple, even contradictory, pathways through which men are remaking their identities within specific workplace settings (Aboim, 2010). Fatherhood in this context appears fragmented, mediated via a range of different ideas about what precisely it meant to be a good lawyer and a good dad. I shall return to this point in the conclusions.

Finally, far from seeing this "package deal" as a problem in and of itself, it is important to locate discussion of fatherhood in law in the context of what was, on the part of these lawyers, a highly reflexive, strategic approach to their life course and career planning; an approach framed by an overarching sense of individual responsibility to manage the self and cope, as discussed above; an approach to career in which, crucially, the experience of

\footnotetext{
${ }^{9}$ Contrast Keate (2014), quoting businessman Mohamed El-Erian "As much as I could rationalise it, as I had rationalised it, my work-life balance had gotten way out of whack, and the imbalance was hurting my very special relationship with my daughter".
} 
fathering shifted as men age and, it was recognised, family transitions occur (see further Green, 2010). In this regard, the commitment called for at a certain stage of career - say, as a trainee, Associate or for some, in the run up to Partnership - was balanced with a recognition that there were limits to how long these working hours would be manageable. Far from seeing the tension between work and home as a problem "forever, you know, you can't keep working like this, you just can't' (Associate), it was suggested by these fathers that the kind of commitment required for a successful City lawyer was something of a 'young person's game'; certainly, more burdensome to those men "especially over the age of around fifty...you know, this doesn't have to be forever' (Associate, my emphasis). For some a relatively early retirement was viewed as a potential option, something which may occur during the "late forties or early fifties" (Partner).

When [I'm] top of equity ladder, getting paid a lot ... I don't want to work past 55, I want to go travelling, play a bit of golf, do all the stuff I missed getting here... yes, I'll do that (Partner)

Whether this reflected the reality or not, with other observations highlighting structural changes in the profession and how easy it could be to become "locked in" to such a way of working, this suggests perception of working cultures and practices as problematic per se must be offset with a recognition that fathering practices and identities can change at different stages of the life course; and it is revealing how the decision to then reassess such a demanding, if financially rewarding, lifestyle was viewed as something that takes place for many men in large law firms at certain moments in life especially; not, crucially, for the fathers in this study, at the point of their first becoming a father but, notably, either when their children had left home or, recognising the high rates of separation and divorce in the profession, in the context of men establishing second families and re-partnering (see, on masculinity in this context, Collier, 2015 p 431). Having children in later life, experiencing personal or family physical or psychological ill-health, uncertainties around promotion to Partnership, bereavement and separation were each referred to by interviewees as common "prompts for reflection" (Partner) on the part of many men in law firms. 
The interviews suggest, that is, perceptions of problems in this area may impact on men who are fathers in ways different to women precisely as aspirations and practices - and, indeed, bodies - change during the life course. This highlights the physical, embodied and psychological dimensions of ageing, an awareness of what these bodies can (and cannot) do in the life course, as an important if rarely explored factor in these debates. For these father-lawyers, crucially, it was not at the point of early parenthood where, for many men in law, as is well-documented in the literature on women in law, this transition to fatherhood tended to be marked by continuity; framed by set of normative assumptions around gender different to those experienced by women lawyers (see also Miller, 2011). It was, rather, later in life that a rebalancing of the rewards of 'the deal' and appreciation of what may have been 'lost' in developing a legal career and 'what counts', a balancing itself alluded to by Neuberger (2014), shifted individual perceptions of the issue. Two comments from female Human Resource directors powerfully capture these ideas:

Men don't think about it at the time ... but when the kids have gone...that's when they think about it, and about what they wish they'd done differently... (HR Director)

Men are very focused ... it's not till they get to 45,50 , to where they want to be, and then they start thinking... whereas women reflect throughout ... they play catch up later (my emphasis) (HR Director)

This suggests that the increasing high-profile debates around poor wellbeing in law and the mental strains and psychological effects of certain working practices in the legal profession, of the kind central to a rapidly growing legal wellbeing literature, should not be seen as somehow fixed. Age and gender can mediate the way assumptions about what constitutes an acceptable work life balance plays out at moments across the individual life course. This further aligns with Vas et al's (2016) observation, in a study of men between 45 and 55 years, on how middle-age is distinctive in both the quantity of stressors experienced and their nature; with a central theme for men in the study being precisely a feeling of being trapped between different (traditional/contemporaneous) gender ideals and, with regard to fatherhood and work, a frequent sense of lost opportunities as men get older (see also Jackson, 2016) 


\section{IV: Concluding Remarks: Unpacking the 'Loving Father of a Happy}

\section{Family'}

Presence has for so long been associated with the conjunction of power and masculinity in law firms that the absence of male lawyers is regarded as more significant than that of women, who may still be regarded as dispensable... Technology is proving to be a means of reaffirming the masculinity of the power and wealth of the legal profession just when confronted by the prospect of feminisation (Thornton 2016a p 13).

My two life values are my drive and desire to be the best and develop my potential, but also family relationships, to be the best son, husband and father, and how do you marry the two? (Partner).

Each of the three themes discussed in this article shed light on different aspects of the dynamics of identity construction as a male lawyer and good father. This reading has challenged the idea that men who are fathers are, in any straightforward way at least, 'unencumbered' figures, somehow unaffected by demands, commitments and responsibilities of parenthood (c.f. the comments of Neuberger, 2014). The reality interweaves a complex array of ideas around gender and work, family and career; ideas about fatherhood that, I have argued, are mobilised and enmeshed within the reproduction of distinctive law firm cultures and gendered ideas of organizational commitment. These 'everyday' practices and processes sustain the gendered hegemony of such elite law firms. Contra human capital theory (Hakim, 2004), drawing out the gendered rationalities and structural, economic and cultural framing of life course decisions relating to parenting highlights the way some culturally specific ideas about men and parenthood, responsibility, lifestyle, social status, consumption, career success and so forth can shape men's fathering practices within specific contexts, doing so in at times contradictory ways.

This further suggests that the changes taking place around fatherhood and men's parenting practices discussed in this paper are meaningful not just at an individual level; in marking, for example, a subjective identity as a good father. They are significant in 
reproducing socially constructed gendered norms within legal organisations; constitutive, that is, of a normative model of fatherhood within law firms. Importantly, this sheds light on why workplace cultures may appear simultaneously so open to and yet so resistant to change. 'Bringing men into the frame', drawing on 'feminist perspectives connected to recent sociological theorising" (Silius, 2013 p 146), thus pushes the boundaries of legal studies and reveals issues hitherto neglected in research on the reproduction of gender inequality in the legal profession. It also tracks to themes within recent feminist labour law scholarship that question the conceptual framing of work-life balance more generally; the continuing conflation, for example, of responsible work with market wage -earning; the erasure of social reproduction within the processes that make up understandings of the legal labour market (see e.g. Connaghan and Rittich, 2005; Fudge, 2011; Stewart, 2011).

Finally, this paper has drawn attention to the importance of engaging with fatherhood in the context of the temporal structures of specific legal workplaces. Work-time cultures, it is known, can vary within and between law firms and legal providers in ways that have powerful effects on individual perceptions of what is deemed to constitute an acceptable practice. Politically, any discussion of 'changing fathers' and improving work-life balance in law firms, therefore, or of engaging men in gender equality projects in the law more generally, must address how gendered interactions are shaped within situated settings and, importantly, by both local-organisational cultures and wider social, economic and structural contexts. Sommerlad (2016) has drawn attention, for example, to structural changes taking place in the legal profession that are resulting in new configurations of gender qualitatively different to those of previous generations of lawyers in terms of these interconnections between gender equality and legal professionalism.

What of the future? As Cunningham (2001) has argued, to move beyond gendered paradigms and support men in their roles as lawyer and father there is a pressing need for change agendas to address both workplace structures, law firm cultures and recruitment/retention economics; and, importantly, for male law firm partners and 
gatekeepers of change to "set the example for associates, thereby resetting firm-wide perceptions" (Cunningham, 2011 p 1008); to question, as Janet Chan observes writing in the context of the legal wellbeing debates, what role legal culture itself has "in sustaining the paradox of satisfied lawyers under working conditions that may be conducive to stress"? (Chan, 2014 p 232).

In this article I have traced how this legal workplace culture shapes, and is shaped by, the gendered practices of men at the interface of work and parenting cultures. As Choroszewicz (2016) notes, for all the ubiquity of policies addressing flexible working, and the cultural resonance of the idea of 'having it all' for both women and men, there remains a reluctance to challenge the male advantage instilled in the dominant prerequisites for career advancement; little evidence, in addition, that outreach policies seeking to develop incentives for fathers to engage with the parenting project have had much impact in the context of lawyers as a professional group (Choroszewicz, $2016 \mathrm{p}$ 135), a point that is supported by this study of father lawyers: ${ }^{10}$

It is not enough that women lawyers are formally granted equal career opportunities if their access to the most professionally favoured positions is still conditioned by their ability to fit into men-tailored professional expectations, working patterns and career commitment. (Hearn et al, 2016, p 65)

This raises questions about whether providing men with, say, a statutory right to paternity and parental leave alone, an approach itself framed by a privatizing of the care burden (Atkinson, 2017), will bring about meaningful change in the legal profession so long as there is little progression of the organisational solutions that make men feel more comfortable about taking such leave. It is intriguing that, in 2018, a major study of the gender pay gap in the UK reports that seniority is a critical driver of pay inequality; and that one possible factor in addressing this is for men to work fewer hours (IPPR, 2018). This study suggests how difficult such an endeavour may be. In this regard, the dominant law firm culture, I have argued, ratifies conventional understandings of the masculine via a logic that dictates it remains an individual and not organisational responsibility to cope

\footnotetext{
${ }^{10}$ Of this sample just one lawyer, a Partner, was engaged at time of interview in a flexible working arrangement.
} 
and 'make it work' (or, indeed, to maintain resilience and wellbeing: Collier, 2016: Parker, 2014); a logic in which it is very difficult for a man to ask for change if it involves rejecting a system that others have made work for them. Yet this male paradigmatic subject, it is important to remember, is not men; fathering is inseparable from broader emotional dynamics of personal life embracing questions, for example, of memory, love and intimacy, desire and vulnerability, place and belonging. These are crucial, yet underexplored, aspects of workplace dynamics in the context of these debates. These 'masculine' identities are never as fixed as they may seem; they are marked by contradictions, tensions, contestations.

The contemporary conversation around gender equality, work life and, more recently, wellbeing in the legal profession thus appears to be framed by something of a paradox. On the one hand, we find over the past five years or so a growing acceptance of formal equality, organisational commitments to tackle diversity, engage men in equality agendas, address growing problems around poor lawyer wellbeing and so forth; to develop a model of lawyering that might better meet the challenges of both a changing economy and shifting demographics around family life (Sturm, 1997, p 146). This is an agenda driven by concerns about organisational efficiency and the business case for change which directly connects to the heightened cultural resonance of challenges to the 'pale, male and stale' men of the law (Ames, 2016; Ashdown, 2015); the masculinity associated with a "white male bourgeois personality of high morality, humanistic...the loving father of a happy family" (Schultz and Shaw, 2013 p 25, my emphasis).

Yet, on the other hand, we also find a distinct sharpening of gendered divisions and cultures in law (Sommerlad, 2016) in which workplace commitment is itself increasingly seen as being unencumbered by the private sphere (Thornton, 2006a); workplace interactions shaped by the market-orientated and hyper-competitive temporal cultures associated with new global elites (Longlands, 2014; Thornton, 2006c; Wald, 2010). This is the context in which the adaptations around fatherhood discussed in this paper highlight the complexity of gendered dynamics of professional identity formation; how old and emerging patterns of gendered identities can co-exist in ways marked by internal 
conflicts and tensions (see Bridges and Pascoe, 2014). Rather than see fatherhood through the static frame of a public/private binary, political-economic and cultural shifts, I have argued, are reconfiguring and adapting gender relations in law in contradictory ways; whereby, more specifically, the embrace of equality agendas runs alongside gendered paradigms that reproduce such divisions in the first place. Meanwhile, interdisciplinary scholarship on men and masculinity in a global setting, I have argued in more detail elsewhere (Collier 2015, 2013), in particular in relation to the idea of transnational men (Hearn, 2015; Hearn et al 2012), usefully relocates these gender equality debates in law within far broader reconfigurations around gender relations, including new forms of business masculinities in the corporate workplace (see further Chow, 2003; Connell, 2014, 2009; Connell and Wood, 2005; Connell and Messerschmidt, 2005; Longlands, 2014). These men in global corporations, exemplified in certain respects by the large City law firm, can be seen to embody a new pattern of hegemonic masculinity in a context of neoliberal globalisation (Madrid, 2017: Connell and Messerschmidt, 2005: Connell and Wood, 2005).

Taking these themes together, therefore, this interrogation of fatherhood in law firms raises important questions about the responsibilities of employers to support the meshing of work and family, and to consider the impact of work scheduling on women's and men's family roles, an issue that continues to be largely side -stepped (Hood and Golden, 1996); an erasure, at the same time, of any questioning about the responsibilities of men to assume caring roles for children and the elderly and, crucially, to take ownership with women for this responsibility of caring (Campbell, 2013). In the light of such tensions and political silences it is unsurprising that there should be considerable uncertainty, as reflected in these interviews, as to just what being a 'good father' entails.

\section{References}

ABOIM, Sofia. (2010). Plural Masculinities. London: Routledge.

AMES, Jonathan (2016) 'Why is the law still mainly male and pale?' (Student Law, The 
Brief - 'Let's Talk about Diversity') The Times 18 Feb 2016

ASHCRAFT, Karen Lee (2013)“The Glass Slipper: 'Incorporating' Occupational Identity in Management Studies." Academy of Management Review, 38, 6-31. ASHDOWN, Julie. (2015). 'Shaping Diversity and Inclusion Policy Within Research' Fordham Law Review, 85 (5): 2249-2275.

ASHER, Rebecca. (2011) Shattered: Modern Motherhood and the Illusion of Equality. Vintage Books: London.

ASHLEY, LOUISE (2010) "Making a Difference?; The Use (and abuse) of Diversity Management at the UK's Elite Law Firms' Work, Employment and Society 24(4) 711-727.

ASHLEY, Louise and Laura Empson (2013) 'Differentiation and discrimination: understanding social class and social exclusion in leading law firms', Human Relations, 66 (2): 219-244.

ATKINSON, Jamie (2017) "Shared Parental Leave in the UK: can it advance equality by changing fathers into co-parents?" International Journal of Law in Context 13 (3): 356-368.

BEKKENGEN, L. (2006) 'Men's parental leave: A manifestation of gender equality or child-orientation' in L. Gonäs and J. Ch. Karlsson (Eds.) Gender segregation: Divisions of work in postindustrial welfare states Aldershot: Ashgate.

BLAGOEV, Blagoy, Laura Empsom and Renate Ortlieb (2017) 'Overwork, Identity and the Autonomy/Control Paradox in Professional Organizations' available at https://www.egosnet.org/jart/prj3/egos/main.jart?rel=de\&reserve$\underline{\text { mode }=\text { active } \& \text { content-id }=1499635422149 \& \text { subtheme } \_i d=1474852915025}$

BLAIR-LOY, Mary (2003) Competing Devotions: Career and Family among Women Executives. Cambridge, MA: Harvard University Press.

BOSTOCK, Jo. (2014) The Meaning of Success: Insights from Women at Cambridge. Cambridge: Cambridge University Press.

BRAITHWAITE, Jo. (2010) "Diversity Staff and the Dynamics of Diversity Policy Making in Large Law Firms' Legal Ethics 13(2): 141-163

BRANDTH, Berit and Elen Kvande (1998) 'Masculinity and child care: The reconstruction of fathering' The Sociological Review, 46(2), 293-313. 
BRIDGES, Trtistan and C.J. Pascoe (2014) 'Hybrid masculinities: New directions in the sociology of men and masculinities' Sociology Compass, 8(3), 246-258.

BUONOCORE PORTER, Nicole (2006) 'Re-defining Superwoman: An essay on overcoming the 'maternal wall' in the legal workplace' Duke Journal of Gender, Law and Policy 13: 55-84

BULLOCK, Lara (2016) 'Young Lawyers Give Up Partnership Dream', Lawyers Weekly, http://www. lawyersweekly.com.au/news/18358-young-lawyers-give-up-partnershipdream,

BURGESS, Adrienne. (2007) The Costs and Benefits of Active Fatherhood: Evidence and Insights to Inform the Development of Policy and Practice. London:

Fatherhood Institute.

CAMPBELL, Beatrix (2013) The End of Equality London: Seagull Books.

CAMPBELL, Iain and Sara Charlesworth (2012) 'Salaried Lawyers and Billable Hours: A New Perspective from the Sociology of Work' International Journal of the Legal Profession 19(1): 89-122.

CARLSON, Dawn, Grzywacz, Joseph and Zivnuska, Suzanne (2009) 'Is Work-Family Balance More Than Conflict and enrichment?' Human Relations 62 (10) 1459-1486.

CHAN, Janet (2014) 'Conceptualising Legal Culture and Lawyering Stress' International Journal of the Legal Profession 21(2): 213-232

CHOROSZEWICZ, Marta (2016) 'Women Attorneys and Gendering processes in Law Firms in Helsinki’ Sosiologia 53: 122-137.

CHOW, Esther Negan-Ling. (2003). 'Gender Matters: Studying globalisation and social change in the $21^{\text {st }}$ Century', International Sociology 18 (3): 443-460

COHEN, Richard B. (2017) 'Can women lawyers ever find equality in Biglaw', Above the Law, available at http://abovethelaw.com/2017/04/can-women-lawyers-everfind-equality-in-biglaw/

CHRISTENSEN, K. (2005) 'Achieving work-life balance: strategies for dual-earner families', in Barbara Schneider and Linda Waite (eds.) Being Together, Working Apart: dual-career families and the work-life balance Cambridge: CUP 
COLLIER, Richard (2016) "Wellbeing in the Legal Profession: Reflections on Recent Developments', International Journal of the Legal Profession, 23 (1): 41-60. (2015). "Naming Men as Men in Corporate Legal Practice: Gender and the Idea of 'Virtually 4/7 Commitment' in Law" Fordham Law Review 83: 23472406.

(2013) "Rethinking Men and Masculinities in the Contemporary Legal Profession: The Example of Fatherhood, Transnational Business Masculinities and Work-Life Balance in Large Law Firms", Nevada Law Journal 13: 101-130 -- (2010) Men, Law and Gender: Essays on the 'Man' of Law. London: Routledge. (1995) Masculinity, Law and the family London Routledge.

COLLIER, Richard and Sheldon, Sally (2008) Fragmenting Fatherhood Oxford: Hart. COLTRANE, Scott (1997) Family Man: Fatherhood, Housework and Gender Equity Oxford: OUP.

COLTRANE, Scott, E.C Miller, T.DeHaan and L.Stewart (2013) 'Fathers and the Flexibility Stigma' Journal of Social issues 69(2): 279-302 COOK, Andrew C.G., Faulconbridge, James R. and Muzio,Daniel (2012) ‘London's legal

elite: recruitment through cultural capital and the reproduction of social exclusivity in City professional services fields' Environment and Planning A, 44: 1744-1762.

CONAGHAN, Joanne and Rittich, K. (2005) 'Introduction: Interrogating the work/family divide' in J.Conaghan and K.Rittich (eds) Labour Law, Work and Family: Critical and Comparative perspectives Oxford: OUP.

CONNELL, Raewyn (2014) 'Global Tides: The Market World and Gender Dynamics' Social Currents 1(1): 5-12

CONNELL, Raewyn. (2012) 'Inside the Glass Tower: the construction of masculinities in finance capital' in P.McDonald and E.Jeanes (eds.) Men, Wage, Work and Family. New York: Routledge. -- (2010). 'Lives of the Businessmen: Reflections on life-history method 
and contemporary hegemonic masculinity', Österreichische Zeitschrift für Soziologie, 35 (2): 54-71.

(2009) 'A Thousand Miles From Kind: Men, Masculinities and Modern

Institutions', Journal of Men's Studies, 16 (3): 237- 252.

(2005) 'Globalization, Imperialism and Masculinities' in Michael

Kimmel, Jeff Hearn and R.W. Connell (eds.) Handbook of Men and

Masculinities. London: Sage.

CONNELL, Raewyn and Julian Wood (2005) 'Globalization and Business Masculinities'

Men and Masculinities, 7 (4): 347-364.

CONNELL, Raewyn and James Messerschmidt (2005) "Hegemonic Masculinity:

Rethinking the Concept." Gender and Society, 19 (6): 829-859.

CONNELLY, Thomas (2017) 'Reed Smith offers flexi-working option to all London

lawyers' available at https://www.legalcheek.com/2017/04/reed-smith-offers-

flexi-working-option-to-all-london-lawyers/

CRARY, Jonathan (2013) 24/7: Late Capitalism and the Ends of Sleep. London: Verso.

CUNNINGHAM, Keith (2001) 'Father Time: Flexible Work Arrangements and the Law

Firm's Failure of the Family', Stanford Law Review, 53: 967-1008

DARBY, Elin (2009) 'No Father Forward' The Guardian 17 January p 1

DERMOTT, Esther (2008) Intimate Fatherhood: A Sociological Analysis. New York:

Routledge.

- (2006). The Effect of Fatherhood on Men's Employment. London: ESRC.

(2001) 'New fatherhood in practice? Parental Leave in the UK'

International Journal of Sociology and Social Policy 4: 145-164

DINOVITZIER, Ronit. (2011) 'The Financial Rewards of Elite Status in the Legal

Profession' Law and Social Inquiry, 36 (4): 971-998.

DOUCET, Andrea. (2006) Do Men mother? Fathering, Care and Domestic

Responsibility. Toronto: University of Toronto Press.

DOWD, Nancy (2010) The Man Question: Male Subordination and Privilege New York: NYU Press.

DREW, Natalie Mei-Chuen, Doita Datta and Jill Howieson (2015) 'The Holy Grail: Work-

Life Balance in the Legal Profession' (2015) 38 (1) UNSW Law Journal 288-322 
DUFF, Liz, and Lisa Webley (2004) Equality and Diversity: Women Solicitors, Research

Study 48, Vol II: Qualitative Findings and Literature Review London Law Society.

ENGEL, G.V. (1970) "Professional autonomy and bureaucratic organization

Administrative Science Quarterly, 15, 12-21:

ELLIOTT, Karla (2016) 'Caring Masculinities: Theorising and Emerging Concept' Men and Masculinities 19(3): 240-259

FLOOD, John (1996) 'Megalawyering in the Global Order: The Cultural, Social and

Economic Transformation of Global Legal Practice' 3(1/2) International Journal of the Legal Profession 169-214

FLOOD, Michael and Richard Howson (2015) (eds) Engaging Men in Building Gender Equality Newcastle, Cambridge Scholars Publishing.

FRANCIS, Andrew and Sommerlad, Hilary (2009) 'Access to legal work experience and its role in the (re)production of legal professional identity' International Journal of the Legal Profession 16(1) 63-86

FREDMAN, Sandra (2014) 'Reversing Roles: bringing men into the frame' International Journal of Law in Context 10 (4): 442-459

FUDGE, Judy (2011) 'Labour as a 'fictive commodity': radical;ly reconceptualising labour law' in G.Davidov and B.Langille (eds) The Idea of Labour law Oxford: OUP.

GILDING, Michael (2010). 'Motives of the Rich and Powerful in Doing Interviews with Social Scientists', International Sociology, 25(6): 755-777.

GOLDMAN, Rebecca, and Burgess, Adrienne (2017) Where's the Daddy? Fathers and Father-Figures in UK Datasets (Condensed Report) Marlborough: Fatherhood Institute.

GREEN, Lorraine (2010) Understanding the Life Course Cambridge Polity. GREGG, Melissa (2010) Work's Intimacy. Cambridge: Polity.

GREGORY, Abigail and Milner, Susan (2011) 'What is "New" about fatherhood? The Social Construction of Fatherhood in France and the UK' Men and Masculinities 14: $588-606$

GROYSBERG, Boris and Robin Abrahams. 2014. 'Manage your work, manage your life' Harvard Business Review, 92 (March 2014): 58-66. 
HAKIM, Catherine (2004) Key Issues in Women's Work: Female Diversity and the Polarisation of Women's Employment London: Routledge

HANLON, Niall (2012) Masculinities, Care and Equality: Identity and Nurture in Men's Lives Basingstoke: Palgrave Macmillan.

HAUARI, Hanan and Hollingworth, Katie (2009) Understanding Fathering: Masculinity, Diversity and Change London, Josepth Rowntree Foundation.

HEADWORTH, Spencer, Robert L. Nelson, Ronit Dinovitzer, and David B. Wilkins (eds.). (2016) Diversity in Practice: Race, Gender and Class in Legal and Professional Careers. Cambridge: Cambridge University Press.

HEARN, Jeff. (2015) Men of the World: Genders, Globalizations, Transnational Times, London, Sage.

HEARN, Jeff, Ingrid Biese, Marta Choroszewica and Liisa Husu (2016) 'Gender diversity and intersectionality in professions and potential professions' in Mike Dent, Ivy Lynn Bourgeault, Jean-Louis Denis and Ellen Kuhlmann (eds) The Routledge Companion to the professions and Professionalism London Routledge.

HEARN, Jeff Marina Bragojević, and Katherine Harrison (eds.). (2012). Rethinking Transnational Men. London: Routledge.

HINSLIFF, Gaby (2015) 'Son, we need to talk... the bitter truth is that something men can't have it all' The Guardian 6 November p 41.

HOBSON, Barbara (ed.). (2002) Making Men into Fathers: Men, Masculinities and the Social Politics of Fatherhood. Cambridge: Cambridge University Press.

HOOD, Jane and Susan Golden (1996) 'Beating Time/Making Time: The Impact of work scheduling on Men's Family Roles' in Carol J Auster (ed) The Sociology of Work Thousand Oaks, CA.

IPPR (2018) The State of Pay: Demystifying the Gender Pay Gap London IPPR.

ISSACSON, Daniella (2017) Law.com 'Where do we go from here? Big Law's struggle with recruiting and retaining female talent', available at http://www.law.com/sites/ali/2017/04/17/where-do-we-go-from-here-big-lawsstruggle-with-recruiting-and-retaining-female-talent/?slreturn=20170808042931 JACKSON, David (2016) Exploring aging masculinities: the body, sexuality and social 
lives, New York, Palgrave Macmillan

JAMES, Grace (2011) 'Mothers and fathers as parents and workers: family friendly employment policies in an era of shifting identities' Journal of Social Welfare and Family law 31 (3): 271-283

JOHANSSON, Thomas and Roger Klinth (2008) 'Caring fathers: The ideology of gender equality and masculine positions' Men and Masculinities, 11(1), 42-62

JUNIOR LAWYERS DIVISIONS (2018a) Supporting resilience and wellbeing in the workplace: guidance for best practice London: Law Society. (2018b) Resilience and wellbeing survey report, London: Law

Society

KAY, Fiona, Alarie, S and Adjei, J. (2013) 'Leaving private practice: how organisational context, time pressures and structural inflexibilities shape departures from private law practice' Indiana Journal of Global Legal Studies 20(2): 1223-1260.

KEATE, Georgie (2014) 'Executive quit after daughter gave him a list of missed milestones’ The Times 26 September 2014 p 11.

KUGELBERG, Clarissa (2006) 'Constructing the Deviant Other: mothering and fathering at the workplace' Gender, Work and Organization 3 (3) 152-173.

KUMRA, Savita. (2015) 'Busy doing nothing: an exploration of the disconnect between gender equity issues faced by large law firms in the United kingdom and the diversity management initiatives devised to address them', Fordham Law Review, 83 (5): 2277-2299

LONGLANDS, Helen. (2014) Men, Masculinities and Fatherhood in Global Finance: A Study of Hegemonic Practices in London, thesis submitted for the degree of Doctor of Philosophy, Institute of Education, University of London, February 2014.

MADRID, Sebastian (2017) “The Good Night kiss': fatherhood among corporate managers and the reconfiguration of hegemonic masculinity in Chile' Norma: International Journal of Masculinity Studies 12 (3-4) 240-255. (2013) 'Getting into the lives of ruling class men: Conceptual problems. Methodological solutions', in Barbara Pini and Bob Pease (eds.), Men, Masculinities and Methodologies

MARSIGLIO, William and Joseph H. Pleck. 2005. 'Fatherhood and Masculinities', in 
M.S. Kimmel, J. Hearn and R.W. Connell (eds.), Handbook of Studies of Masculinities. London: Sage.

MARSIGLIO, William, Kevin Roy and Greer Litton Fox (eds.). 2005. Situated

Fathering: A Focus on Physical and Social Spaces. Oxford: Rowman and Littlefield.

McGLYNN, Clare (1998) The Woman Lawyer Oxford: OUP

MCQUEEN, Fiona (2017) 'Male emotionality: 'boys don't cry' versus 'it's good to talk', NORMA: International Journal for Masculinity Studies 12:3-4, 205-219

MILLER, Tina. (2011a). Making Sense of Fatherhood: Gender, Caring and Work. Cambridge: Cambridge University Press. - (2011b) 'Falling back into gender? Men's narratives and practices around first-time fatherhood' Sociology 45(6) 1094-1109

MORGAN, David. (1996) Family Connections: An Introduction to Family Studies. London: Polity.

MOSSMAN, Mary Jane. (2006) The First Women Lawyers: A Comparative Study of Gender, Law and the Legal Professions. Oxford: Hart.

MUZIO, Daniel and Tomlinson, J. (2012) 'Researching Gender and Diversity in Contemporary Professions and Professional Organizations' Gender Work and Organization 19(5), 455-466

NEUBERGER, Lord (2014) Rainbow Lecture on Diversity 2014, House of Commons, 12 March. Available at: http://supremecourt.uk/docs/speech-140312.pdf,

NICOLSON, Donald and Julian Webb. 2005. 'Public rules and private values: fractured profession(alism)s and institutional ethics', International Journal of the Legal Profession, 12 (2): 165-172.

PAREKER, Christine (2014) 'The 'moral panic' over psychological wellbeing in the legal profession: a personal or political ethical response?' University of New South Wales Law Journal, 37(3), 1103-1141:

PLICKERT, Gabrielle and John Hagan (2011) 'Professional work and the timing of family formation among young lawyers in US and German cities' International Journal of the Legal profession 18(3): 237-261.

PINNINGTON. Ashly and Jorgen Sandberg. (2013) 'Lawyers Professional Careers: 
Increasing Women's Inclusion in the Partnership of Law Firms', Gender, Work and Organization, 20 (6): 616-631.

RANSON, Gillian (2012). 'Men, paid employment and family responsibilities:

Conceptualizing the 'working father' Gender Work and Organization, 19(6), 741-761.

RHODE, Deborah (2001) Balanced lives: Changing the Culture of Legal Practice

Chicago American Bar Foundation

RUDMAN, Laurie and Kris Mescher (2013) 'Penalizing Men Who Request a Family

Leave: Is Flexibility Stigma a Femininity Stigma? Journal of Social Issues 69(2) $322-340$

RUSPINI, Elisabetta and Isabella Crespir. (2016) Balancing Work and Family in a Changing Society: The Fathers' Perspective. London: Palgrave.

SANDBERG, Jorgen and Ashly Pinnington (2009): "Professional Competence as Ways of Being: An Existential Ontological Perspective.” Journal of Management Studies, 46, 1138-1170.

SCHULTZ, Ulrike and Gisela Shaw (eds.). (2008) Women in the World's Legal Professions Oxford: Hart. - (2013) 'Gender and Judging: Overview and Synthesis' in Ulrike Schultz and Gisela Shaw (eds) Gender and Judging, Oxford: Hart.

SILIUS, Harriet (2003) 'Making sense of gender in the study of the legal profession' International Journal of the Legal profession 10(2) pp 135-148.

SOMMERLAD, Hilary (2016) “"A pit to put women in”: professionalism, work intensification, sexualisation and work-life balance in the legal profession in England and Wales', International Journal of the Legal Profession, 23 (1): 61-82. - (2010) Minorities, merit and misrecognition in the globalized profession, Fordham Law Review, 80: 2481-2512.

---------- (2007) Researching and theorizing the processes of professional identity formation, Journal of Law and Society, 34 (2): 190-217.

(2002)'Women Solicitors in a Fractured Profession' International Journal of the Legal Profession 9(3), 213-234

SOMMERLAD, Hilary and Peter Sanderson (1998) Gender Choice and Commitment: 
Women Solicitors in England and Wales and the Struggle for Equal Status Aldershot: Ashgate.

SOMMERLAD, Hilary, Webley, L., Duff, L, Muzio, D and Tomlinson, J. (2010) Diversity in the Legal Profession in England and Wales: A Qualitative Study of Barriers and Individual Choices London: Legal Services Board

STANLEY, Kate. (2005) Daddy Dearest? Active Fatherhood and Public Policy. London: IPPR.

STEWART, Anne (2011) Gender, Law and Justice in a Global Market Cambridge: CUP.

STURM, Susan P. (1997) 'From Gladiators to problem solvers: connecting conversations about women, the academy and the legal profession' Duke Journal of Gender, Law and Gender 4: 119- 147

TIENARI, Janne, EEro Vaara and Susan Meriläinen (2010) 'Becoming an International Man: Top manager masculinities in the making of a multinational corporation' Equal Opportunities International, 29(1), 38-52

THORNTON, Margaret. (2016a) 'The flexible cyborg: work-life balance in legal practice', Sydney Law Review, 38 (1): 1-21. (2016b) 'Work/life or work/work? Corporate legal practice in the twentyfirst century', International Journal of the Legal Profession, 23 (1): 13-39. -- (2016c) 'Squeezing the life out of lawyers: legal practice in the market embrace' Griffith Law Review 25(4), 471-491 (2014) Hyper-competitiveness or a balanced life? gendered discourses in the globalisation of Australian law firms, Legal Ethics, 17 (2): 153-176. (1996) Dissonance and Distrust: Women in the Legal profession, Oxford: Oxford University Press. -- (1988) 'Authority and corporeality: the conundrum for women in law' Feminist Legal Studies, 6: 147.

THORNTON Margaret and Joanne Bagust. (2007) 'The gender trap: flexible work in corporate legal practice, Osgoode Hall Law Journal, 45 (4): 773-811.

TOWNSEND, Nicholas. (2002) The Package Deal: Marriage, Work and Fatherhood in Men's Lives. Philadelphia: Temple University Press. 
TURKLE, Sherry (2011) Alone Together: why we expect more from technology and less from each other New York: Basic Books.

VAS, Szilvia, Mark Forshaw and Sarah Grogan (2016) 'Men's experiences of middleage: an interpretative phenomenological analysis' NORMA: International Journal for Masculinity Studies 11:2, 71-88

WACJMAN, Judy. (2015) Pressed for Time: The Acceleration of life in Digital Capitalism. Chicago: University of Chicago Press.

WALD, Eli. (2010) 'Glass Ceilings and Dead Ends: Professional Ideologies, Gender Stereotypes and the Future of Women Lawyers at Large Law Firms', Fordham Law Review, 78: 2245-2288.

WALLACE, Jean (2006) 'Work Commitment in the Legal Profession: a study of Baby Boomers and Generation Xers' International Journal of the Legal profession 13(2) 137- 151.

WEBLEY, Lisa. (2015) 'Legal Professional De(Re)Regulation, Equality, and Inclusion, and the Contested Space of Professionalism within the Legal Market in England and Wales' Fordham Law Review 83(5), 2349-2367

WEBLEY, Lisa, and Elizabeth Duff (2007) 'Women solicitors as a barometer for problems in the legal profession - time to put values before profits'? Journal of Law and Society 34(3) 374-402

WELDON-JOHNS, Michelle (2016) 'From modern workplaces to modern families - reenvisioning the work-family concept' Journal of Social Welfare and family law 37(4), 395-415.

WIMMER, Andreas and Schiller, Nina Glick (2002) 'Methodological Nationalism and beyond: nation-state building, migration and the social sciences' Global Networks 2(4) 301-334.

*** 